RERIATE DE MAULES

Campinas-SP, v.38, n.2, pp. 1053-1075, jul./dez. 2018

\title{
COMO TOMAR "O COMBOIO DAS ONZE"? OU O SurREALISMO SEgUndo JORge DE SENA
}

\author{
Marcelo Pacheco Soares ${ }^{1}$
}

Resumo: Este artigo se propõe a ler uma narrativa do escritor português Jorge de Sena pouco visitada pela crítica: o conto "O comboio das onze", de Andanças do demónio. Investiga-se a relação do texto e do seu autor com o movimento vanguardista Surrealismo e, mais além, o seu posicionamento crítico-teórico acerca dessa estética, a fim de, a partir daí, propor uma nova chave interpretativa para esse texto.

Palavras-chave: Jorge de Sena; Surrealismo; conto português do Século XX.

"Se eu quisesse, enlouquecia."

(Herberto Helder, 2005, p. 11)

A despeito da cada vez mais ampla fortuna crítica de que goza a obra do escritor português Jorge de Sena, são bastante escassas as leituras do seu conto "O comboio das onze", quarto título da coletânea Andanças do demónio, publicadaoriginalmenteem196o. Quiçáacausadetalalheamento crítico seja o seu enredo insólito, hermético, aparentemente incoerente. Assim, vejamos: em uma estação de trem, um homem (Pancrácio), que espera pelo comboio das onze, dirige-se à barraca do guarda, a qual se assemelha à cabine telefônica do fim da rua, e o mata; recolhe da janela teias de aranha e mistura-as ao sangue do guarda e a cotões de sua roupa, guardando o produto em uma caixinha que leva consigo; senta-se sobre o cadáver e atende a uma mulher de branco (Infesta), que também espera pelo comboio; quando o veículo chega, ambos entram na carruagem da terceira classe, em que estão um jovem saloio que dorme e uma mulher

1 Professor do Instituto Federal de Educação, Ciência e Tecnologia do Rio de Janeiro: $<$ marcelo.soares@ifrj.edu.br>. 
de meia-idade ainda virgem; com o trem em movimento, Pancrácio conversa com Infesta, oferece-lhe uma pitada do referido preparado que traz e tira-lhe a roupa, movimento percebido pela mulher de meia-idade, que, por sua vez, imagina despir o saloio, raspar-lhe os pelos do rosto aproximando-o de feições cada vez mais adolescentes e o trazer para se deitar em seu colo, enquanto ele dorme e sonha; após um ato sexual que a narrativa apenas sugere ter sido consumado, Infesta, cujas formas físicas desfizeram-se subitamente, foge (ou literalmente desaparece) quando o comboio para em nova estação, restando nas mãos de Pancrácio apenas os trapos que eram o vestido que ela usava; o protagonista então retira o sobretudo, revelando a sua nudez, após auxiliar a mulher de meia-idade a despir o saloio, já desperto; depois ela se deita e espera enquanto Pancrácio enfia-lhe pela boca os trapos; por fim, ele volta à cabine onde está ainda o guarda morto, em que o telefone toca insistentemente, e o ressuscita com as palavras de influência bíblica: "Ergue-te e caminha!".

Mesmo que tenhamos omitido passagens significativas do texto nessa tentativa de síntese do seu enredo, temos uma amostra da sua instantânea ilegibilidade. Dado o resumo apresentado e tomando esse comboio como representação do próprio conto, ou seja, assumindo que a narrativa se desenvolve num processo de discursividade autorreflexiva já nos seus primeiros sintagmas (o que, cremos, repete-se em seu desenvolvimento, segundo demonstraremos), ao menos algo é de imediato coerente: que a narração define, logo no seu período inicial, que "a locomotiva ultrapassava a compreensão da expectativa” (SENA, 1984, p. 53). ${ }^{2}$ Isto é, sobre esse comboio-conto, aquilo que nós leitores expectamos não será suficiente para compreendê-lo por inteiro. Possivelmente por isso, como dizíamos, a crítica via de regra não teça considerações mais aprofundadas a respeito da narrativa e atenha-se a classificá-la, em maior ou menor grau, como surrealista, modo antes de justificar uma passagem rápida por ela do que de efetivamente dela se aproximar.

Assim, Vera Lúcia Vouga (1982, p. 39) observa no conto "um estilo surrealizante”. Maria de Fátima Marinho (1987, p. 181), em seu meritório trabalho acerca do Surrealismo em Portugal, considera que, na obra de Sena, esse é o "conto mais próximo da estética bretoniana", conquanto dedique a ele não mais do que uma página, sendo mais da metade citações do próprio texto. Mais recentemente, Margarida Braga Neves (2009, p.

2 Deste ponto em diante as citações referentes ao conto em análise mencionarão apenas o número da sua respectiva página. 
19) afirma que "o texto, tanto pela sua desarticulação como pelo humor deliciosamente absurdo que nele se insinua, denuncia a filiação surrealista que Sena insistentemente reivindicou", mas, mesmo reconhecendo o conto como "excepcional neste conjunto" (p. 19) que são as Andanças do demónio, não aprofunda a leitura. E, por fim, Óscar Lopes (1984, p. 328) é mais categórico ao enquadrá-lo como "um texto surrealista em que vários recursos mais ou menos felizes da absurdez narrativa apenas deixam coar uma atmosfera, apesar de tudo bastante homogênea, de uma experiência de vida ferroviária nos subúrbios de Lisboa por meados do século". Nossa pesquisa bibliográfica, que, sem provavelmente ter sido completa, reconhece-se como exaustiva, ${ }^{3}$ alcançou apenas uma análise mais alentada do conto, promovida por Newton de Castro Pontes (2013, pp. 161-165), em sua tese de doutorado, defendida em 2013, na qual, por algumas páginas - e optando por ignorar a questão da possibilidade de inclusão ou não do texto no gênero surrealista -, investiga a filiação do poeta português ao campo semântico do demoníaco, tão caro à obra seniana, concluindo: " $\mathrm{O}$ comboio das onze' é a perfeita expressão desse demonismo".

Esse último não é, no entanto, o caminho que pretendemos percorrer. Tão pouco nos será alternativa possível considerar o conto um simples exemplo de narrativa surrealista, ao menos não em termos ortodoxos, e veremos que essa discussão merece maior exame. Para a nossa viagem, que esperamos ser mais longa do que as percorridas até aqui pela crítica, escolhemos tomar "O comboio das onze" de maneira distinta, optando por embarcar, dentre os infinitos vagões possíveis dos significados produzidos pela leitura (metáfora, a propósito, que poderíamos empregar no processo de leitura de qualquer obra artística), em uma carruagem que cremos seguir ainda vazia, na qual se pense essa narrativa não necessariamente como surrealista, mas como um conto metalinguístico que discute uma poética possível e alternativa para o Surrealismo.

\section{A LUZ DO FAROL}

Estamos na plataforma da estação à espera do comboio (a locomotiva que temos a expectativa de compreender) e o primeiro sinal que temos da aproximação dele é a luz do seu farol, o posto avançado a que se refere

3 E agradecemos à professora Gilda Santos e ao professor Francisco Cota Fagundes, nomes fundamentais da crítica seniana, pelas consultorias bibliográficas que nos confirmaram relativa ausência crítica específica sobre esse conto. 
Antoine Compagnon (1996, p. 53) em seu estudo sobre O trabalho da citação, ou seja, a primeira aproximação se dá pela epígrafe do conto: "Quand un oeuf casse des oeufs, c'est qu'il n'aime pas les omelettes". ${ }^{4}$

Trata-se de um dos 152 provérbios ao gosto dos dias de hoje, elaborados em 1925 pelos conhecidos poetas do Surrealismo francês Paul Éluard e Benjamin Péret, o que de fato evidencia a relação da narrativa com esse movimento artístico, como observou até agora a crítica. Todavia, o citado provérbio surrealista é uma inequívoca piada, uma alteração paródica de um ditado popular - "Não se pode fazer omeletes sem quebrar os ovos" -, o que nos leva à cogitação inicial de que poderia ser o conto não uma narrativa surreal, mas um texto que se relaciona com esse estilo pelo viés anedótico, pela via do pastiche, análogo ao discurso da epígrafe - e muitas passagens do conto, marcadas por um humor de fato bastante condizente com o Surrealismo, o humor deliciosamente absurdo apontado por Braga Neves, ratificam essa hipótese -. Não será por acaso, aliás, que Sena (1988, p. 255), em artigo de 1978 sobre o Surrealismo, refira esses poetas com ironia, reduzindo Péret a "fiel sacristão do papa" (ou seja, de André Breton) e Artaud, a um "louco".

Esse ajuizamento leva a crer que a seleção da epígrafe faz do conto mais uma discussão do tema - sob uma ótica que não se desvia do registro satírico - do que uma homenagem à estética surrealista ou, ainda bem menos, um produto dogmático seu, mesmo que pudesse parecer isso à primeira vista. Aliás, o fato mesmo de percebermos ser alimentado esse logro que aqui identificamos - o de que "O comboio das onze" seria uma peça surrealista (e as antes citadas incursões da crítica comprovam o sucesso desse ardil) -, encaminha-nos outra vez para a assertiva inicial, que dá conta de que essa locomotiva ultrapassa a compreensão da expectativa. Tal expectativa justamente nos iludiria, fazendo crer que se trata nesse caso de um texto surrealista e que possivelmente funciona também como marcador dessa mesma característica, qual seja, de que, no texto, o comboio das onze, em seu "atraso habitual" (p. 55), não passe precisamente às onze horas, não sendo, a rigor, das onze, revelando-se assim algo distinto daquilo que se apresenta inicialmente, no título do conto. Ou seja, "O comboio das onze" não é sobre um comboio efetivamente das onze, assim como esse pretenso texto surrealista não é efetivamente um texto surrealista.

4 "Quando um ovo quebra ovos, é porque não gosta de omeletes." 
Cabe ainda observar que o provérbio recriado pelos poetas surrealistas é uma apropriação e uma transformação do real hodierno vulgar, representado pelo dito popular, essa frase exaustivamente repetida de geração em geração. Certamente essa opção pelo enunciado do ditado original, cristalizado e pronto para ser repetido, configuraria o que o Manifesto Surrealista de André Breton (1983, p. 175), de 1924, reconhece como um dos instrumentos voltados a "reduzir a imaginação à escravidão", utilizados pelos "vulgarizadores de toda espécie” (p. 207). Ou seja, os poetas, ao se extraviarem dessa escolha comum pelo elementar, fácil, acessível e, por isso mesmo, vulgar, cumprem seguramente o papel que se espera do homem surrealista, "que, advertido do choque sucessivo de todos os outros [homens], não se dá por vencido, parte de onde ele veio e, por um outro caminho diferente de um caminho razoável, chega aonde pode" (p. 207). Em suma: ao manipular o provérbio popular - esse lugar-comum da fala irrefletida vulgarizada de uma imaginação escravizada e incapaz de elaborar seu próprio discurso -, parte-se exatamente de onde todos vêm para alcançar caminho diferente do considerado socialmente razoável, desvendando, por uma rota por conseguinte invulgar, a surrealidade (uma realidade afinal mais complexa, uma realidade mais vasta, como Jorge de Sena terá a oportunidade de descrever) ocultada nesse (e por esse) real hodierno.

Ora, há no próprio procedimento de recorte epigráfico efetuado aqui por Sena um saldo semelhante. Ao trazer para o posto avançado do seu conto o provérbio transmudado por Éluard e Péret, o autor, explorando evidentemente um fenômeno que se observa em todo processo epigráfico, empreende da mesma forma uma apropriação e, por isso, promove também uma transformação do sentido original desse texto do qual ele se apropria, assim (res)siginificando-o a partir da sua (re)contextualização. Desse novo significado transmudado - especificamente pertinente não apenas ao aspecto, a que nos referíamos, satírico, anedótico e crítico do conto em relação ao Surrealismo, mas ainda ao seu contexto, definamos assim, socioliterário - trataremos adiante.

\section{A CABINE DO MAQUINISTA}

Com o comboio-conto na estação aguardando que os leitores efetuem o embarque, cometamos a indelicadeza de investigar sua casa de máquinas, sua cabine de direção, e analisar seu condutor - claro está, o autor Jorge de Sena -, bem como sua relação com o Surrealismo e com 
os grupos de poetas, escritores e pintores que oficializaram essa estética em Portugal.

Ora, em terras lusas, é certo que Jorge de Sena apresenta algum significativo grau de pioneirismo no que diz respeito ao Surrealismo. Talvez isso não ocorra propriamente na sua prática poética, pois, ainda que Maria de Fátima Marinho (1987, p. 120) admita que "sua obra [de Sena] tem mais de um traço devedor dos ditames surrealistas e não pode ser ignorada em qualquer estudo sério" e que o próprio Sena postule, para o volume Perseguição, de 1942, um reconhecimento do uso dos métodos apregoados pelo movimento francês, ele mesmo relativiza tal filiação, afinal pouco ortodoxa, ao considerar, sobre o processo criativo da composição dos poemas desse seu primeiro livro, que ele se colocava: "na linha do Surrealismo caminhando ao longo dela” (SENA, 1988, p. 251). Por outro lado, sem dúvida Jorge de Sena ocupa no país uma das posições de proa na discussão teórica dessa vanguarda artística, o que mais de uma vez Marinho (1987, p. 45) menciona:

Casais Monteiro, embora se tenha mantido sempre mais ou menos afastado dos movimentos surrealistas organizados e tenha sido sempre marginalizado por Cesariny e o seu grupo, é dos primeiros ensaístas (juntamente com Jorge de Sena) a preocupar-se com a teorização e divulgação do Surrealismo em Portugal.

Aqui, Marinho refere-se, evidentemente, a Mário Cesariny, decerto o mais importante representante do Surrealismo em Portugal, poeta todavia com quem Jorge de Sena estabelecerá longo conflito em que se confundem não apenas oposições teóricas, mas também atritos pessoais, sobretudo após o artigo de Sena sobre a exposição surrealista de 1949 ser publicado na revista Seara Nova sob o título "Surrealismo (a propósito de uma exposição e de algumas publicações conexas)", que se encerra com o seguinte poema:

\section{Ode ao Surrealismo por conta alheia}

Que levas ao colo,

embrulhado em sarrafaçais transcritos mau olhado abomináveis

trutas e outros preconceitos?

Um sacerdote? Um gato? A timidez?

Que transportas silencioso, imóvel, como dormindo, no xaile pespontado e verde com que limpas o suor, o sêmen, as fezes, 
tudo o que abandonas, ofereces, vendes, expulsas, injetas, convocas, reprovas, descreves, etc.?

Embalas e não respondes.

Temes a polícia, os tapetes, o capacho, o telefone, as campainhas de porta, as pessoas paradas pelas esquinas reparando em por de baixo das roupas das outras que passam?

Temes as palavras?

Temes que saiam versos, lágrimas, casamentos, satisfações apressadas em campos de arrabalde?

Temes os partidos, os artigos de fundo, os banqueiros, os capelistas, a inflação, as úlceras do estômago ou sociais?

Que transportas ao colo em silêncio e num xaile?

É a vida? Anúncios luminosos? Casas econômicas? O mar?

Irmãos? Reivindicações? Um livro?

Embalas e não respondes.

É a vida? A noite que cai? As luzes distantes? Um gesto?

Um olhar? Um quadro? Uma poesia lírica?

(Oportunamente interrompida pela chegada de uma pessoa conhecida)

(SENA, 1988, p. 232)

Ora, as falsas odes senianas não são propriamente raras em sua produção artística, o que parece ser o caso desse poema. Ana Maria Gottardi (2002, p. 70), ao levantar essa característica da poética dele, não deixa de citar esse poema como exemplo:

Algumas odes, revelando influência modernista, usam do tom épico e de exaltação da ode pindárica numa perspectiva irônica, criticando ao invés de louvar; é o caso de "Ode à mentira" e "Ode ao Surrealismo por conta alheia", de versos exageradamente longos e de tom agressivo, que lembram odes de Álvaro de Campos, e também de "Ode ao amor", com um tom ambíguo e acentuadamente erótico que hesita entre crítica e exaltação.

É claro que não ignoramos que Sena negou o valor jocoso desses versos em um dos seus últimos artigos, a que já fizemos referência, datado de pouco mais de um mês antes de sua morte, em 1978: "Um dos cavalos de batalha, se não me engano, era um poema com que os artigos terminavam, 'Ode ao Surrealismo por conta alheia', que considero dos melhores e mais sérios poemas que já escrevi e foi considerado um perverso ataque 
satírico" (SENA, 1988, p. 254). 5 Todavia, não nos parece injusto tomarmos como retórica essa declaração, cuja confiabilidade estaria comprometida em razão do envolvimento pessoal do autor com as circunstâncias, demanda, aliás, que se evidencia em todo o artigo - espécie de catarse que ele produz já no fim da vida, referente a essa espécie de espoliação intelectual que sofreu, promovida pelos surrealistas portugueses -, cujo título, vale destacar, é uma vez mais, dada seu desproporcional tamanho, declaradamente irônico:

Notas acerca do Surrealismo em Portugal, escritas por quem nunca se desejou nem pretendeu precursor de coisa alguma, ainda que, cronologicamente, o tenha sido, por muito que isto tenha pesado a muitos surrealistas, exsurrealistas, etc., do que se não excluem mesmo eminentes pessoas que contam entre os melhores e mais dedicados amigos do autor. (SENA, 1988, p. 245)

Assim, é afinal compreensível (e mesmo mais do que legítimo) que a leitura defendida décadas mais tarde por Sena não seja a mesma que, à época, os escritores dos grupos surrealistas em Portugal realizaram, certamente entendendo como crítica não apenas os "versos exageradamente longos" e o "tom agressivo", como Gottardi observa, mas ainda a enumeração caótica que se desenvolve indefinidamente e sem aparente objetivo no poema.

Poema este que, é pertinente destacar, apenas se encerra em função de uma interrupção avaliada pelo poeta como (e a escolha vocabular produz então um juízo de valor) oportuna, além da repetida imagem de uma

5 É verdade também que os desentendimentos não se limitavam a esse episódio, como levanta Sílvia Marisa dos Santos Almeida Cunha (2008, p. 99): "Jorge de Sena teve uma relação algo conflituosa com os surrealistas, apesar de ter sido talvez o primeiro poeta português a ensaiar as soluções poéticas vanguardistas inspiradas no movimento francês. Um dos motivos que estariam na origem da sua diferença com Mário Cesariny seria talvez a recusa deste em disponibilizar a sua ficha biobibliográfica para que Sena a incluísse no terceiro volume das Líricas Portuguesas. Tendo-a incluído contra a sua vontade, Cesariny dirige as seguintes palavras ao nosso autor: 'Jorge de Sena não só inclui os poetas em questão como lhes estabelece fichas biobibliográficas tão retorcidas como a cabeça dele”". No artigo citado, de 1978, Sena também faz referências à organização das Líricas Portuguesas e à dificuldade de obter de Cesariny os dados biográficos e bibliográficos dele, assim como sua aceitação para figurar no volume. No entanto, tal qual em outros espaços teórico-acadêmicos em que escreveu sobre o poeta surrealista, Sena é de certa forma econômico nas críticas, as quais alcançam mesmo o seu, digamos, ápice na liberdade oferecida pelo espaço literário, nas controversas Dedicácias - poemas também estudados por Sílvia Cunha, vazados no mais autêntico estilo das medievas Cantigas de Escárnio -, em cuja peça dedicada a Cesariny o mínimo que Sena faz é, em função da assumida opção homossexual do algoz, apelidá-lo de "Maria Cesarina". 
figura interpelada, que traz silenciosamente escondido algo que embala e não revela, numa alusão à absoluta ausência de sentido (e não um sentido mais real do que a realidade vulgar que viria a caracterizar o sobrerreal) da estética surrealista mais ortodoxa.

Por fim, a ode satiriza um suposto e caricato temor dos surrealistas de que, na aleatoriedade do seu trabalho, chegassem por acaso a um produto final dotado de um sentido absolutamente corriqueiro, algo nunca de todo impossível, mas que poria em xeque a espontaneidade da sua escrita. Jorge Luis Borges (1957, p. 21), na sua sabedoria crítica e literária, em mais de uma oportunidade (e contos como "A biblioteca de Babel" e "Pierre Menard, autor de Quixote" baseiam-se nessa discussão) debate sobre as probabilidades de elaborar uma obra literária a partir da combinação aleatória dos limitados elementos da escrita, como patenteia a passagem do conto "El inmortal": "Homero compuso la Odisea; postulado un plazo infinito, con infinitas circunstancias y cambios, lo imposible es no componer, siquiera una vez, la Odisea”. ${ }^{6}$ Relacionando à discussão borgiana, o Surrealismo e o método de produção conhecido como cadavre exquis, ${ }^{7}$ que lhe é constitucional, correspondem ao receio de acidentalmente produzir uma Odisseia, por exemplo, ou antes qualquer eventualidade corriqueira da vida, o que está satirizado em versos como: “Temes as palavras?/ Temes que saiam versos, lágrimas, casamentos, satisfações apressadas em campos de arrabalde?”.

A figura que circula no poema, ocultando algo ao colo, concretiza-se desse modo como uma espécie de tu-poético da ode, eéela na verdadequem se identifica com o Surrealismo, ou seja, a referência é significativamente externa à voz do poema, afastando dessa estética, por consequência, o seu eu-poético inquiridor. Tal consequência, aliada ao fato de estarmos diante não de uma Ode Surrealista, mas de uma Ode ao Surrealismo (e, enfatizemos, "por conta alheia"), faz crer que também por pura retórica, no artigo de 1947 em que ela é apresentada, Sena (1988, p. 228) a tenha

6 "Homero compôs a Odisseia; postulado um tempo infinito, com infinitas circunstâncias e mudanças, o impossível é não compor, sequer uma vez, a Odisseia."

7 Embora seja de amplo conhecimento público do que se trata o método de produção da poética surrealista conhecido por "cadáver esquisito", remetamo-nos à definição teórica fornecida na Antologia do cadáver esquisito, de Mário Cesariny (1989, p. 95): "Jogo de papel dobrado que consiste em fazer compor uma frase ou um desenho por várias pessoas, sem que nenhuma delas possa aperceber-se da colaboração ou colaborações precedentes. O exemplo, tornado clássico, que deu nome ao jogo, está contido na primeira frase obtida deste modo: O cadáver-esquisito-bebera-o-vinho-novo". 
antes definido como "uma ode absolutamente surrealista”, explicitamente contrariando o próprio título e seu conteúdo - seria também, nesse caso, por assim dizer, a ode das onze que não é das onze -, quando (a exemplo do que cuidamos poder ler em relação ao conto que motiva esse artigo) será essa ode muito menos uma composição surrealista do que um poema que se refere ao Surrealismo (e que, mais concretamente, se dirige ao próprio poeta surrealista, representado por esse tu-poético).

Muito a propósito, tal condição da voz poética da ode, a de quem observa de fora o desenrolar de cenas surrealistas, não se afasta da curiosa posição em que o protagonista Pancrácio surge no conto em análise, sujeito oculto que abre a narrativa - " $Q$ Aguardava a passagem do comboio" - e que oculto se mantém ainda por alguns verbos, até que, após assistir à mutação do cenário - "Pouco a pouco diluíram-se os conversadores, tanto mais que, em verdade, não estavam lá” (p. 54) -, é afinal sintaticamente identificado. E justamente na condição de observador: "Foi então que o espectador inicial, muito lentamente, atravessou a linha e se dirigiu à barraca do guarda" (p. 54, grifo nosso), ou seja, é nesse momento que, ao atravessar a linha (linha férrea em leitura mais imediata, mas fronteira entre mundos para um exame que encare o signo simbolicamente), o protagonista - que, mesmo não sendo o narrador, é quem oferece o ponto de vista com que se identificará o leitor nos primeiros movimentos do texto -, ganha existência no espaço surreal do conto, adentrando esse universo do qual então, a princípio, não fazia parte.

Mas não nos precipitemos na análise da narrativa. Observemos antes que, em relação à ode, a reação dos grupos surrealistas portugueses - é verdade que bem ao gosto do próprio movimento - foi bastante belicosa, como fica manifesto no artigo "Os Surrealistas dizem de sua justiça", publicado por Mário Cesariny e Pedro Oom na Revista Sol, no mesmo ano da ode seniana, que no qual os autores enumeram críticas à sociedade, classificadas como "pacoviadas", dentre elas as dedicadas a Sena e seu poema, è̀ Seara nova:

Pacoviada - esta, imperdoável, dada a alguma dignidade com que este escritor costuma servir as suas migas críticas - as considerações de Jorge de Sena acontecidas na revista Seara Nova, e terminadas com uma "Ode ao Surrealismo por conta alheia”, da qual o menos que se pode dizer é que excedeu todas as suas congêneres no estilo insinuoso, maneta e sacristão.

$[\ldots]$

Pacoviada o "ideário seareiro" que auto-autoriza Câmara Reis a recusar a publicação de uma resposta nossa aos já citados considerandos de Jorge de Sena por não estar ela (a resposta) à altura da "Seara"! (Pacoviada estilo: o rabo 
do gato de fora - De Como Se Fabrica Uma Censura Interna Numa Revista que Chora Ante a Censura Oficial). (CESARINY, 1989, pp. 33-34)

Tais conflitos, no entanto, não se limitam a embates com Sena ou outros escritores e críticos externos aos círculos surrealistas, uma vez que é bastante conhecida a cisão que sofre o movimento, por divergências teóricas diversas, quando Cesariny funda um grupo dissidente após escrever a António Pedro alegando que sua decisão de afastar-se do Grupo Surrealista de Lisboa é "por não acreditar nem que seja Grupo e ainda menos que seja Surrealista” (MARINHO, 1987, p. 45). Sena (1988, p. 252) lamenta em várias oportunidades a conduta desagregadora dos membros do grupo, referindo-se com certa ironia a "quando o Surrealismo chegou a Portugal em forma de grupos logo multiplicados, em 1947", ou ainda, mais abertamente, às "divisões e hostilidades em que o incipiente movimento logo se cindiu" (p. 249) e, afinal, de modo mais severo, ao "triste espectáculo das suas brigas e quesílias com insultos e semelhantes coisas que fazem as delícias de quem não merece a décima parte do respeito que a maioria dos surrealistas, ou ex-idem, merecem" (p. 252). Vê Sena nisso uma absoluta contradição em relação ao próprio conceito elementar da vanguarda surrealista, que levantaria um valor que perpassa também toda a humanista poética seniana - a liberdade do homem -, o que o leva a pregar, no artigo de 1949, que

[...] deve denunciar-se um dos piores procedimentos do Surrealismo corrente, que é a preocupação dogmática, ortodoxista, etc., de só fazer isto ou aquilo, de especializar a cultura, numa matéria que é, por sua natureza, a-dogmática, a-ortodoxa etc., e para a qual só será prejudicial o que for feito escolarmente. (SENA, 1988, p. 222)

Trata-se da mesma contradição - aliás, um dos cinco paradoxos da modernidade - que Antoine Compagnon (2010, p. 63), chamando-a de "terrorismo teórico", apontaria décadas mais tarde em sua análise do comportamento que André Breton adotara desde a ruptura com Tristan Tzara, por desacordos quanto ao Dadaísmo. Pensamos que essa crítica ao movimento e esse dever de denunciá-lo, explicitados por Sena, são aquilo que o conduz à epígrafe de "O comboio das onze" e, por conseguinte, à escrita do conto.

Observemos que a narrativa é datada de "1948-196o" ao seu final, ou seja, sua primeira elaboração, dado o ano inicial, teria surgido não apenas no auge do movimento surrealista português, mas também no domínio 
de suas rupturas, e, sendo assim, tal é o contexto socioliterário que antes mencionamos como modificador da epígrafe, permitindo-nos decodificar os seus sintagmas sob a seguinte expressão matemática: ovo(s) : poeta(s) = omeletes : poesia. Isso nos encaminha à outra transformação, a que nos referíamos, do dito popular já convertido por Éluard e Péret, a qual estimamos ser algo como: Quando um poeta quebra poetas, é porque não gosta de poesia - o que, afinal, condiz com a crítica que Sena elaborara e expusera. Assim, quiçá por isso, no conto, Pancrácio matasse o guarda; ou seja, a causa desse assassinato aparentemente desproposital, que ocorre logo após o momento em que o protagonista "atravessa a linha" (diante portanto do sentinela que, à porta desse universo surreal, poderia impedir o seu embarque no comboio surrealista, como os artistas dos grupos auto-oficiais portugueses se arvoravam no direito de fazer com as incursões, nessa poética, de Sena e de outros escritores externos aos seus círculos), o motivo do assassinato, dizíamos, talvez fosse exatamente a função desse profissional de policiar, vigiar, fiscalizar: seu potencial para, em última instância, ser símbolo de um reacionarismo teórico-literário que encontra par em Cesariny e Breton (embora seja verdade que a narrativa não enfatiza esse traço no, não por acaso, secundário personagem e nem mesmo lhe legue tratamento antipático, e leitura outra a respeito de sua morte -, ou, mais precisamente, da ordem de ressurreição que receberá de Pancrácio ao fim do conto - preferiremos estrategicamente preservar para momento mais oportuno deste artigo).

Para além, contudo, dos exames de Jorge de Sena sobre o comportamento dos surrealistas portugueses, é precisamente na divergência teórica, ou seja, no conceito que cada um desenvolve dessa estética vanguardista, que reside aquilo que sustenta a dissensão entre autores como Sena e Cesariny, segundo Maria de Fátima Marinho (1987, pp. 44-45) esclarece ainda:

Outro dos problemas candentes é o de uma demarcação do que o movimento português entende por Surrealismo e a sua filiação do lado de Breton ou de Aragon, isto é, do lado de um surrealismo mais literário ou de um mais politicamente comprometido. É evidente que Cesariny se situa declaradamente ao lado de André Breton, atacando simultaneamente Aragon e os portugueses, Casais Monteiro e Jorge de Sena, como defensores de um falso e estranho surrealismo. Em uma carta a Alexandre O’Neill e António Domingues, Cesariny enumera tudo o que a seus olhos constitui o erro e o mal-entendido (o "abandono do automatismo psíquico", o "relegamento dos fenômenos ditos de acaso", “o oquismo daliniano de dialéctica” não "empenhada em transformar 
o real", "a defesa barata de Luis Aragon"), defendendo o surrealismo "vivido $e$ teorizado tanto por Breton como por Calas".

Surge aí um dos entendimentos importantes de Sena acerca do Surrealismo, deduzido das apreciações de Cesariny as quais não podemos exatamente classificar como errôneas, uma vez que de fato o autor de "O comboio das onze" é um poeta cujo fazer literário a crítica reconhece como algo racionalista, elaborador de uma poética moderada pela lógica. Por isso, por princípio, Sena oferece uma prática que parece avessa ao acaso ou ao automatismo psíquico - ao menos ao conceito de automatismo em que Cesariny e seus companheiros creriam, segundo Sena (1988, pp. 221-222) mesmo reconhece ao expor que, na sua concepção,

[...] o uso e abuso da escrita automática, de jogos como o "cadavre exquis" etc., não significa que, epistemologicamente, a atitude surrealista seja intuicionista, como não deve significar que os surrealistas sejam crentes convictos em virtudes mágicas do acaso. Significa, exactamente, a convicção experimental de que a realidade é muito mais vasta do que a pretende um cientismo atrás do qual se esconde um imenso terror da complexidade do real; e a convicção, igualmente experimental, de que as virtualidades humanas são mais poderosas, violentas e terríveis que quanto pretendem os fariseus de qualquer espécie. Significa, ainda, a convicção de que só o livre exercício lúdico de todas as apetências humanas, por absurdas que sejam, é capaz de harmonizar a vastidão da realidade natural e a intensidade das virtualidades humanas, tornando feliz o homem.

Outro conceito fundamental, ao qual já havíamos aludido, está acima reiterado por Sena: ao mencionar as potencialidades libertadoras do Surrealismo, o autor refere-se também à sua competência para levar o homem a enxergar o real para além da visão superficial que os fariseus limitadamente lhe transmitem, confirmando o seu alinhavar com Aragon e com o Surrealismo mais comprometido politicamente, como distinguido por Marinho. Desse modo, “O comboio das onze", sendo um conto que defende a visão de Sena sobre o Surrealismo, apresenta na figura de Infesta precisamente esse valor. Lembremos que, na descrição do corpo da personagem, um corpo feminino potente e livre, chamam a atenção de Pancrácio "sobretudo as mãos, muito lépidas e libertárias" (p. 55), na quais, enfatizando então a importância desse valor, o protagonista se demorará mais tarde a beijar (devotamente, como sugere a posição em que se posta para o ato): "Pancrácio ajoelhou, pegou nas mãos de Infesta, e, durante o tempo necessário ao consumo da saliva em excesso, lambeu-he, uma por uma, as inserções dos dedos" (p. 56). 
Finalmente, sobre a relação do Surrealismo com a liberdade - e a necessidade, por isso, do trabalho coletivo (daí, novamente, a forte crítica às desavenças no seio do movimento em Portugal) -, Sena (1988, p. 219) ainda endossa:

\begin{abstract}
Nada do que signifique luta do homem com as limitações exteriores ou interiores que o homem a si próprio tem imposto deveria ser alheio ao surrealismo. Neste sentido, a liberdade, a luta humana pela liberdade individual ou colectiva, é profundamente surrealista. E é precisamente a consciência de que a liberdade é precária se não é garantida pela liberdade alheia, que, por um lado, o leva a fazer sua a frase célebre de Lautréamont acerca da poesia, que deverá ser feita por todos e não por um.
\end{abstract}

Uma vez conhecedores dos ânimos e das ideologias de condução do maquinista dessa locomotiva, podemos agora seguir viagem, preferindo tomá-la, como evidente já deixamos, não pela carruagem em que a crítica (quando o faz, e normalmente de modo deveras breve) embarca - na qual, lembremos, se lê "O comboio das onze" como um exemplo de conto surrealista (ou surrealizante, ou próximo à estética bretoniana, ou de filiação surrealista) -, mas por uma carruagem outra, em que se perceba a narrativa de forma distinta: como um conto sobre o Surrealismo, e um Surrealismo segundo Jorge de Sena.

\title{
3. A CARRUAGEM
}

Alguns signos da narrativa demonstram essa chave interpretativa que propomos. Um deles é o título do seu primeiro subcapítulo: "A passagem de nível”. É claro que sua referência imediata leva-nos ao campo semântico ferroviário, no entanto, ao mesmo tempo, o signo alerta-nos já nos seus primeiros instantes, reiterando a epígrafe, que estamos passando, desde o início, para outro nível surrealista que não o ortodoxo apregoado quase, digamos, fascistamente pelos bretons e cesarinys. Assim, possivelmente esse comboio siga viagem, como Sena confessara sobre seu primeiro livro de poemas, também na linha do surrealismo mas caminhando ao longo dela. E, sob um discurso absolutamente irônico que simula aceitação das críticas que o autor sempre recebeu dos surrealistas portugueses, a julgar pelo título do subcapítulo seguinte - a carruagem de $3^{a}$ classe, o nosso segundo signo -, estaremos de passagem para um nível do Surrealismo classificado como inferior: o falso e estranho Surrealismo que Marinho recupera do discurso de Cesariny equivaleria a um Surrealismo de terceira 
classe, ao menos conforme fora sempre ajuizada por tais grupos qualquer circulação de Jorge de Sena por essa estética.

Um terceiro signo que nos interessa é a pavimentação do espaço onde se aguarda o comboio, composto por saibro, algumas vezes referido, ainda que todas elas no primeiro subcapítulo, sempre a denunciar uma presença em função do som provocado pelos passos sobre ele: "Alguém se aproximava pela valeta fora; ouvia-se estalar o saibro, passo a passo" (p. 54); "O saibro estalava mais próximo" (p. 54); "O guarda não respondeu, nem podia pensar nisso, ocupado como estava em regressar a cadáver depois de sentir-se banco de jardim, rodeado de aragem e de estalar de saibro" (p. 55). Acreditamos que a insistência de que se ouça o saibro para identificar a presença de algo constitui uma espécie de convocação da narrativa e que não pode ser desprezada. Por isso, pensemos: o saibro é produto da alteração de rochas de quartzo-feldspáticas, figurando granulometricamente entre areia e cascalho, e, por isso, no jargão geológico, é tido como um material incoerente. Ora, nada mais conveniente então do que a escolha desse chão (leia-se então a base, o fundamento do conto, daí portanto que ele se faça presente apenas nesse primeiro subcapítulo, no início da construção da narrativa, reforçando essa sua função de alicerce), já que afinal o Surrealismo caracteriza-se exatamente pela alteração da percepção do real vulgar para uma visão que perceba a existência de uma realidade mais vasta, cujo resultado é uma matéria supostamente incoerente em que "harmonizam-se a vastidão da realidade natural e a intensidade das virtualidades humanas" (resgatando aqui, bastante intencionalmente como se verá, palavras teóricas de Sena já citadas).

Essa oposição (ou, melhor dizendo, essa coexistência) entre realidade natural e realidade mais vasta evidencia-se no sistema de duplos que se estende pelo conto, os quais descreveremos a seguir. Iniciemos, por exemplo, pela guarita do guarda da estação, cuja semelhança com a cabine telefônica ao fim da rua "era flagrante" (p. 54), de modo que aquela se sobrepõe a esta, quando, após o homicídio, o telefone tocará dentro da guarita e, ao termo do conto, estando este ainda sob o mesmo som do aparelho, revela-se que agora o guarda é que está morto na cabine telefônica, e não mais na barraca em que foi assassinado. Poderíamos citar também a explícita (porque textualmente confessada) duplicação intertextual da Pietá (tema que se repete em diversas ocasiões da História da Arte, da representação do Cristo agonizante ou morto nos braços 
da mãe, da qual a versão de Michelangelo é a mais famosa) na seguinte cena: "E a mulher de meia-idade, à luz vacilante da carruagem, tinha o saloio atravessado no colo, com a cabeça caída e os braços caídos, e compunha um grupo curiosíssimo, uma espécie de Pietá, que apenas outros gestos multiplicavam" (p. 58). E esse processo de intertextualidade multiplicadora, aliás, encontra-se representado na "conversação em voz baixa, [todavia] ouvida apenas a grande distância" (p. 53), ou nos "sons [que] se perdiam, continuamente renovados" (p. 54), trechos que se extraem da parte inicial do conto e estabelecem alguma relação com esse quase silêncio dos objetos artísticos, o qual se faz ouvir em distâncias espaciais e temporais, sussurro que se perde para surgir renovado, trazendo ademais leituras possíveis para a presença no conto do telefone e do próprio comboio, símbolos da supressão (ou da relativização) das distâncias - o que a narrativa, contudo, ironicamente, na crítica ao modelo surrealista vigente que nela reconhecemos, associa de modo pejorativo a autoclismos (ou seja, a descargas de sanitários).

Nesse inventário de duplos, há ainda, resgatando a relação do Surrealismo com o onírico, o sonho do saloio, em que se relacionam, sugerindo a sua semivigília, os acontecimentos que o cercam (as carícias sexuais de Infesta e Pancrácio; a gradativa aproximação, que progride do olhar ao toque com o calcanhar e com as mãos e ao abraço, da mulher de meia-idade cada vez mais tomada pelo desejo) e o ambiente com que sonha, resultando na sua própria gradativa excitação, insinuada nas suas "calças justas, sempre mais justas" (p. 56), apesar de o sonhoaparentemente (mas, ressaltemos, apenas aparentemente) não ter teor erótico: “dormia equilibrado mansamente num dilúvio de pinheiros que um luar esfiava por recantos negros, onde se ouviam ruídos de algumas saias e de cinturas dobradas para o chão" (p. 56). E eis que a própria manifestação imagística dos raios luminosos da lua rompendo as fendas deixadas pelos espaços negros entre os pinheiros projeta o ato sexual que ocorreria próximo a si, percebido nos estímulos sonoros, julgamos que provocados pelo casal protagonista, de roupas que caem e corpos que lascivamente se movem em direção ao chão. Daí que não fossem os olhares concupiscentes da mulher, "que se aguçavam por ingénuos cálculos, o que repercutia no sono do saloio, mas aquela ascensão peculiar, arripiando-lhe sub-repticiamente os pêlos das pernas, alastrando como uma pele cariciosa por todo o corpo oculto na massa de roupa contraída e sono titilado que ele estava sendo" (pp. 56-57), de modo que o saloio, no ritmo agora já indubitavelmente 
erótico do balançar do comboio, "bamboleava-se não já do embalo do andamento, mas sonhava que...” (p. 57). Tal período, exatamente assim interrompido, antecede o subcapítulo seguinte e, portanto, poderia ser o conteúdo desse sonho, no qual Infesta e Pancrácio conversam, mas em que o saloio segue dormindo, sugerindo uma estrutura de duplicação (e mais: multiplicação novamente) em mise en abyme, em que o saloio sonha que o saloio sonha que o saloio sonha que...

Mais sutilmente, reconhecemos a duplicadora relação entre o cesto de arroz e mostarda que carrega o saloio e o que carrega "uma mulher de cesto, com uma criança ao colo" (p. 54) - que também tomara o comboio mas à qual não mais se faz menção no conto -; e ainda, por extensão, "a pequenina mala [...] inteiramente preta e de couro falso" (p. 57) de onde a mulher de meia-idade retira a escova de unhas com que irá polir os pelos do saloio, enquanto ele dorme; e mesmo, metonímia de todos, a caixinha da algibeira em que Pancrácio traz o peculiar unguento que preparou. São todos instrumentos diversos em que os personagens conservam e trazem matérias várias, algumas reveladas, a maioria delas não, deixando talvez ao leitor, nesse último caso, a opção por realizar perguntas que não serão respondidas e em nada se distanciariam de questionamentos como $O$ que levas ao colo, embrulhado em sarrafaçais? ou Que transportas ao colo, em silêncio e num xaile?.

Pois todas essas duplicações são representações do próprio processo mimético do Surrealismo, na medida em que propõem não duplos opostos, mas, como num movimento circular (ou algo espiralado) de $360^{\circ}$, polos que, ao menos do ponto de vista bidimensional, sobre-põem-se, de modo que, de uma realidade mais comum, mais cotidiana, mais habitual, surja-lhe, transformando-a, essa forma de uma sobrerrealidade. E julgamos que a mais importante dessas manifestações de duplicidade no conto tem origem no casal protagonista.

Não será desprezível assinalarmos que um duplo presumível para o casal Pancrácio-Infesta, externo a esse conto, mas não à Obra de Jorge de Sena, seja o Físico e D. Urraca, da novela $O$ fisico prodigioso. Enquanto Pancrácio assemelha-se, com seus unguentos, a uma espécie de bruxo ou alquimista (como o nosso Físico pseudomedieval), Infesta - cuja descrição do corpo se assemelha à da nudez de D. Urraca em sua primeira cena, quando convalesce à espera da cura do Físico - revela-se dotada da mesma experiência e de semelhante conhecimento sexual que os a protagonista feminina da novela seniana, tanto pela forma como "Infesta afastava os 
joelhos e escorregava sabiamente pelo banco, sibilando muito devagar" (p. 56, grifo nosso), quanto pelo fato de que apenas ela, e não Pancrácio, sabe se eles realmente concretizaram a relação carnal: "Pancrácio por seu lado não saberia dizer se ela estava nua ou não, se era Infesta ou não, se a possuíra ou não. E perguntou a Infesta. Ela recordava-se" (p. 58). Mas sua resposta (uma vez mais) não é revelada, permitindo que Infesta, potencializando a sua particular sapiência, abrigue um conhecimento que não é prontamente concedido nem mesmo ao leitor - que segue suspenso nas perguntas que lhe cabem do texto surrealista -, a não ser que tenha ele a sensibilidade de decodificar a sugestiva imagem da cena imediatamente posterior, com a cesta do saloio caindo do banco enquanto "um arroz-doce escorria e espalhava pelo chão" (p. 58), como a representação da manifestação física masculina do gozo, o que, todavia, também não fica claro se este seria de Pancrácio ou mesmo do cada vez mais adolescente saloio, agora a sofrer de polução noturna, ou ainda, o que seria quiçá mais plausível, de ambos.

No entanto, a despeito dessa aproximação possível entre Pancrácio e Infesta e o Físico e D. Urraca, evidentemente que o duplo mais imediato do casal protagonista de "O comboio das onze" é mesmo o formado pela mulher de meia-idade e pelo saloio, cujas atitudes são fortemente influenciadas pelos movimentos daqueles. Pancrácio e Infesta, como seria até desnecessário destacar, são distinguidos por uma aura de irrealidade: na indefinida cor dos cabelos de Infesta ou da pele de Pancrácio, no diálogo aparentemente incoerente que travam, no preparado de sangue de guarda e teia de aranha de que se alimentam, na transformação dela em algo disforme e no seu desaparecimento e, é claro, nos seus nomes insólitos. Enquanto isso, o saloio e a mulher de meia-idade são apresentados como personagens comuns, e chamando-os comuns queremos não somente aproximá-los de uma realidade exterior ao conto (considerando-os, pois, mais "realistas"), mas também percebê-los como figuras cotidianas, sem peculiaridades que os destaquem da massa, convencionais, o que se reforça pelo fato de, ao contrário da excentricidade dos nomes do outro casal, nem mesmo serem batizados pela narrativa, que lhes evita uma individuação. Ainda assim, seus movimentos irão se espelhar nos de Pancrácio e Infesta, revelando-os duplos especularmente opostos ao casal principal.

Aliás, o impúbere saloio e a mulher de meia-idade virgem são, na verdade, eles mesmos iguais-opostos um do outro, pois, nas suas polarizações etárias, que vão se acentuando no decorrer do conto, os 
dois encontram-se em nível semelhante de inexperiência sexual, mesmo que a do saloio seja apenas presumida, dada a sua condição adolescente, enquanto a da mulher de meia-idade é textual, não somente pela adjetivação explícita que dá conta de sua virgindade, mas também pela sua "amargura seca, hesitante e tímida, [...] sem audácia, sem viscosidade" (p. 56), que deriva numa - opostamente à Infesta - "ignorância total de como se despe um homem que dorme" (p. 56). A tensão de natureza sexual entre eles irá se estabelecer a partir das sugestões provocadas pelas ações dos protagonistas, tanto que Pancrácio, após o desaparecimento da sua companheira, irá efetivamente conduzir a iniciação nessa matéria do saloio adolescente e da intocada mulher. Para Newton de Castro Pontes (2013, p. 162), aliás, "Pancrácio e o mundo fazem parte de sistemas axiológicos diferentes" - e temos aí outra vez demonstrada a validade da metáfora da ultrapassagem da linha -, todavia, o erotismo presente na narrativa e promovido pelo primeiro casal representa justamente, ainda segundo o autor (p. 164), um "meio de reunir elementos divididos", "de misturar organicamente os seres, restituir sua integridade perdida" (PONTES, 2013, p. 165). Para nós, essa reunião e essa restituição de integridades dialoga com a explicitada coexistência entre realidade natural e realidade mais vasta, as quais Jorge de Sena defende que o Surrealismo deve promover. E Pancrácio e Infesta compõem exatamente o que podemos classificar como, tal qual o saibro, um material incoerente (em relação a um mimetismo com o real) que promove uma alteração da realidade vulgar dos outros dois personagens, sendo dessa forma também o palimpsesto sobre o qual a narrativa do saloio e da mulher de meia-idade é reescrita - reescrita, cabe destacar, num registro libertário que as relações sexuais potencialmente gestam e que figura como o importante valor da obra de Sena, que o autor crê encontrar no Surrealismo, movimento, segundo ele, como vimos, que é eficiente instrumento de difusão e defesa dessa liberdade.

Por fim, resta-nos falar do guarda, vítima de homicídio por Pancrácio, a quem o protagonista, no entanto, ordena que se levante ao fim da narrativa, fazendo parecer que morrer ou ressuscitar são eventos absolutamente estocásticos. Ora, em um conto que, segundo acreditamos, propõe a discussão do Surrealismo, não é aleatória essa opção por se referir ao assassinado sempre como cadáver, ao invés de morto, corpo, defunto, finado, falecido (todos sinônimos possíveis, cuja profusão levantamos para evidenciar que essa reiterada e específica seleção vocabular do termo cadáver não pode ser inocente), uma vez que, em uma narrativa com tal 
temática, a expressão Surrealismo + cadáver pode sempre resultar na imediata associação ao cadavre exquis. Ademais, esquisito será justamente um atributo possível para esse cadáver que, afinal, contrariando a lógica, "morreu, consciente de que mal fôra ferido" (p. 55), isto é, manteve, embora morto, suas atividades psíquicas (quase "brascubasianamente"), ao menos no discurso irônico do narrador que aponta as improváveis “ações", "opções” e "emoções" de que o cadáver é sujeito: "O guarda não respondeu, nem podia pensar nisso, ocupado que estava em regressar a cadáver depois de sentir-se banco de jardim" (p. 55, grifos nossos).

Nesse sentido, as considerações de Jorge de Sena sobre o método criativo do Surrealismo conhecido por cadáver esquisito são-nos agora bastante pertinentes. Como já apontamos, o autor julga que "o uso e abuso da escrita automática, de jogos como o 'cadavre exquis', não significa que, epistemologicamente, a atitude surrealista seja intuicionista, como não deve significar que os surrealistas sejam crentes convictos em virtudes mágicas do acaso" (SENA, 1988, p. 221). Tal posicionamento do autor é que provocou, ao menos em parte, a crítica de Mário Cesariny apontada por Maria de Fátima Marinho (1987), em que, recordemos ainda um pouco mais, o poeta surrealista condena o "abandono do automatismo psíquico" e o "relegamento dos fenômenos ditos de acaso" por parte de Sena. Ora, para além disso, o autor de "O comboio das onze", no artigo a respeito da Exposição Surrealista de 1949, analisa comparativamente da seguinte forma duas das obras pictóricas nela exibidas:

A. Pedro traça algumas considerações acerca do individualismo - "é assim, pela total individualização, que se torna indispensável uma actividade colectiva”. Discordo, no entanto, de que um quadro colectivo seja feito ignorando cada um dos colaboradores a contribuição dos outros. Se esse método do "cadavre exquis" se presta a curiosas "trouvailles", parece-me que a actuação colectiva e o respectivo resultado como resultado só serão favorecidos pela mútua influência dos elementos plásticos de cada um. Como, nas antigas oficinas, era confiado a cada pintor um pormenor, de cuja execução era perito, aqui se acrescentariam e sobreporiam os desenvolvimentos temático-formais, que o alheio trabalho sugerisse, em lugar de se "colarem" fragmentos demasiado pessoais para constituírem a unidade de um quadro. Não sei se teria assim sido feito o outro quadro exposto, de F. Azevedo e Vespeira; de certo modo, é mais uno. (SENA, 1988, pp. 227-228)

Assim é que, no diálogo incoerente (ou, reiteremos, ao menos aparentemente incoerente) entre Infesta e Pancrácio, ela (em seu já destacado saber) vaticina: "Nem todas as teias, sabes?, são das que nos servem. Umas há que não se misturam. E outras vezes é o sangue 
dos guardas que não liga com elas" (p. 57). Ora, pelas evidências que levantamos desde o início de nossa investigação e que nos levam a considerar "O comboio das onze" como uma discussão ética e estética do Surrealismo, podemos ler essa frase como uma agora mais que manifesta metáfora da crítica mesma que Sena fez ao quadro da Exposição de 1949 e do método do cadáver esquisito em geral: há teias que não se misturam, há sangue de guarda que não se liga com elas, porque fragmentos demasiado pessoais não se colam para constituírem a unidade; o resultado, para dar liga, para ser mais uno, carece de mútua influência e não de intuicionismo ou virtudes mágicas do acaso -; e eis o Surrealismo segundo Jorge de Sena, estranho aos olhos de Cesariny por racionalizar o método do cadáver esquisito e, de certa forma, abandonar o automatismo psíquico ${ }^{8}$ e relegar os fenômenos ditos de acaso em prol de uma obra que promova a efetiva participação coletiva dos seus artífices. Daí que, de posse desse saber que Infesta lega a Pancrácio, a única atitude a ser tomada por ele ao termo do conto seja o de dizer ao guarda morto palavras semelhantes às que, nas narrativas bíblicas, Jesus dirige a Lázaro para ressuscitá-lo: "Ergue-te e caminha!". Desse modo, a ressurreição do guarda do conto evidencia, por fim, a necessidade de que o cadáver esquisito seja uno, dê liga, revele finalmente o que leva ao colo -, em suma, seja um cadáver vivo.

\section{AS PRÓXIMAS PARADAS}

Essa viagem, evidentemente, aqui não se pode esgotar. Sigamos nela então, com o desejo/convite de que em estações próximas nos deparemos com mais passageiros, a embarcarem nessa ou em outras carruagens, ocupando os lugares ainda demasiadamente vazios dessa locomotiva e usufruindo do passeio ao, de alguma maneira, também tomarem "O comboio das onze".

8 Se retomarmos a datação do conto (1948-196o), teremos a indicação de que o texto, publicado originalmente em 1948, passou por revisão antes de sua nova publicação em 1960, o que não necessariamente ocorreu com outros títulos das Andanças do demónio, que manteve a datação anterior à da compilação do volume, sugerindo que não sofreram modificação, casos de "Razão de o Pai Natal ter barbas brancas" e "A comemoração", por exemplo. Isso potencializaria a relação de estranhamento entre "O comboio das onze" e a estética do Surrealismo, já que tal processo de revisão vai de encontro, por princípio, à escrita automática que essa estética defende. 


\section{HOW TO GET ON “O COMBOIO DAS ONZE”? OR THE SURREALISM ACCORDING TO JORGE DE SENA}

Abstract: This article proposes to read a narrative of the Portuguese writer Jorge de Sena little visited by the critic: the short story "O comboio das onze”, of Andanças do demónio. Is investigated the relationship between the text and its author with the avant-garde movement of Surrealism and, further, its critical-theoretical positioning on this aesthetic, in order to propose a new interpretative key to the story.

Keywords: Jorge de Sena; Surrealism; Portuguese tale of the zoth century.

\section{REFERÊNCIAS}

BORGES, Jorge Luis. El Aleph. Buenos Aires: Emecé, 1957.

BRETON, André. Manifesto do Surrealismo (1924). In: TELES, Gilberto Mendonça. Vanguarda europeia e Modernismo brasileiro. Petrópolis: Vozes, 1983, pp. 174-208.

CESARINY, Mário. Antologia do cadáver esquisito. Lisboa: Assírio \& Alvim, 1989.

COMPAGNON, Antoine. O trabalho da citação. Trad. Cleonice P. B. Mourão. Belo Horizonte: Editora UFMG, 1996.

COMPAGNON, Antoine. Os cinco paradoxos da modernidade. Trad. Cleonice P. B. Mourão. Belo Horizonte: Editora UFMG, 2010.

CUNHA, Maria dos Santos Almeida. Un chant novel. A inspiração (neo)trovadoresca na poética de Jorge de Sena. Dissertação (Mestrado em Estudos Portugueses) Universidade de Aveiro, Aveiro, 2008.

GOTTARDI, Ana Maria. Jorge de Sena - uma leitura da tradição. São Paulo: Arte e Ciência, 2002.

HELDER, Herberto. Os passos em volta. Rio de Janeiro: Azougue Editorial, 2005.

LOPES, Óscar. Os contos de Jorge de Sena (problemas de um assumido realismo). In: LISBOA, Eugénio. Estudos sobre Jorge de Sena. Lisboa: Imprensa Nacional - Casa da Moeda, 1984, pp. 319-337.

MARINHO, Maria de Fátima. O Surrealismo em Portugal. Lisboa: Imprensa Nacional Casa da Moeda, 1987.

NEVES, Margarida Braga. Os contos impublicáveis de Jorge de Sena. Revista Metamorfoses, Lisboa, Caminho, n. 9, 2008, pp. 17-28.

PONTES, Newton de Castro. Formas do conto: estudos sobre as tradições do conto de expressão inglesa e portuguesa. Tese (Doutorado em Teoria Literária) -Universidade Federal de Pernambuco, Recife, 2013. 
Remate de Males, Campinas-SP, v.38, n.2, pp. 1053-1075, jul./dez. 2018 - 1075

SENA, Jorge de. O comboio das onze. In: Antigas e novas andanças do demónio. Lisboa: Edições 70, 1984, pp. 53-59.

SENA, Jorge de. O fisico prodigioso. Rio de Janeiro: 7Letras, 2009.

SENA, Jorge de. Sobre o Surrealismo. In: Estudos de Literatura Portuguesa - III. Lisboa: Edições 70, 1988, pp. 213-26o.

VOUGA, Vera Lúcia. Sena ficcionista. Revista Humanidades, Porto, Associação de Estudantes da FLUP, n. 1, 1982, pp. 37-43. 